\title{
O povijesno-književnim (re)konstrukcijama Matoša
}

ABSTRACT. Škvorc Boris, O povijesno-književnim (re)konstrukcijama Matoša (About the [Re]Constructions of Matoš in Histories of Literature). „Poznańskie Studia Slawistyczne” 7. Poznań 2014. Publishing House Science and Innovate, pp. 221-236. ISBN 978-83-63795-79-5. ISSN 2084-3011.

This article deals with the constructions of „Matoš” in Croatian histories of literature. Central for the study is Alum Munslow's thesis that history cannot be ,non-narrative”. In that respect the relationship between hi/story and narrative genre is studied on examples of how the ,character" of Antun Gustav Matoš, one of the most famous Croatian writers from the beginning of twentieth century, is both perceived and constructed in historical narrative and in philological context that is discursively circled by the narrative.

Keywords: Antun Gustav Matoš; narration; nation; history and story; ideologemes and mythologemes; philological level of analytical process; reconstruction and deconstruction in reading literary history

Ni ideja strukture koja izdvaja različite sfere objektivna značenja poštujući njihovu statičnu originalnost, a ni ideja geneze koja pretjerano prelazi s jednoga područja na drugo, ne čine se pogodnim za razjašnjavanje problema temelja objektiviteta, koji je već Husserlov problem. (...) I najbezazlenije pribjegavanje pojmu geneze, a osobito pojmu strukture pretpostavlja barem strogo razgraničenje. (...) No to prethodno razgraničenje može pripadati jedino fenomenološkoj kritici. Ona je uvijek prva i može odgovoriti na pitanja kao (...) što je fizička stvar, što je psihološka stvar, što je povijesna stvar itd. itd? - (a to su) pitanja na koja su strukturalne ili generičke tehnike više-manje dogmatski podrazumijevale odgovor. 
U ovom ću se radu baviti narativima, odnosno re/konstrukcijama Antuna Gustava Matoša kod suvremenih hrvatskih književnih povjesničara. Pri tome će u središtu biti uspostavljanje razlike među sintetičkim, povijesno-književnim i analitičkim, odnosno književno-povijesnim pristupima. Cilj rada nije stilska ili naratološka analiza naracije (nacije), već pokušaj uvida u kulturološki široko zamišljen (retorički i pripovjedno) način konstrukcije ideologema koje u struci i nacionalnoj kulturi olako stereotipiziramo i bez dopunskih objašnjavanja, čak i u prostoru izvan povijesno-književnog diskursa, razumijevamo kao „Antun Gustav Matoš” i „hrvatska moderna” (u ovom povijesno-književnom primjeru). Ti se termini onda osamostaljuju u smislu podrazumijevanja njihova stereotipizirana značenja (okamenjenog označitelja), kako u struci, tako i u široj upotrebi, odnosno u sustavu školstva, kulturalnim praksama i nacionalnim, političkim i drugim diskurzivnim korištenjima/trošenjima. Najprije će biti riječi o pozicioniranju tih ideologema unutar književnog, kulturnog i političkog polja, a onda o konstrukciji mehanizama njihove aproprijacije u promijenjenim odnosima moći, kako u kanonu, tako i u poetici, koja ima ulogu uspostavljanja razine politike (političnosti) teksta (i obrnuto, naravno). Nakon toga slijedi uvid u probleme književne povijesti kao zasebne epistemologije i/ili područja fikcijskog narativnog s posebnim naglaskom na retoričko-narativne mehanizme koji stipuliraju fikcijski i/ili ideološki obilježeni karakter upisan unutar površinskih slojeva zamjetnog broja povijesno-književnih sinteza. Pri tome su u središtu zanimanja ideje povijesti kao priče i književno-povijesnih sistema kao fabularnih (i fabuliranih) cjelina u kojima pojedini pisci i amblemi (kao A.G.M., na primjer) često zauzimaju značenje koje je kud i kamo više (i manje) od povijesne rekonstrukcije. Postajući likovima (kao A.G.M., Šenoa ili Krleža, na primjer), oni prestaju biti protagonisti povijesno izvlaštene domene upisane u pojedinačno vrijeme (historicističko shvaćanje) ili objekt naturalizacije, kao proizvod pojedinačnoga suvremenog čitanja (novohistoricistička kritika diskursa/critical discourse reading), već zauzimaju prostor predmnijevane stereotipizirane konstrukcije koja se prenosi iz teksta u tekst, iz povijesne re-konstrukcije u rekonstrukciju, gubeći, kako svoju povijesnu jednokratnost, tako i pozicioniranje u odnosu na re-konstrukcije (pri)povijesnoga iz različitih sinkronijskih sučeljavanja. U sugestijama nagoviještenima ovim 
tekstom ukazuje se na to kako ovako ispričani „likovi” jedino dekonstrukcijom jedinstvenog književno-povijesnog teksta utkanoga u dogovorenu dijakroniju mogu ponovno biti upisivani na tri razine: u diskurzivne zakonitosti (i odnose u sustavu moći) vremena pripovijedanja, u imaginarni prostor upisanog vremena fikcije i u diskurzivne zadanosti hegemonije vremena čitanja/tumačenja/korištenja teksta (a kasnije ću to u jednom opširnijem analitičkom radu razraditi). Utoliko je tema A.G. Matoša zahvalna u propitivanju modeliranja historijske pri/povijesne hegemonije i onih napuklina u sistemu koje traže ponovno čitanje pri/povijesnih konstrukcija oko kojih već postoji fenomenološki upisani konsenzus (cf. gornji citat iz Derridaova teksta).

\section{2.}

Riječ je o bavljenju problemom odnosa tradicionalne povijesti književnosti kao rekonstrukcije povijesno-književnih činjenica i, uvjetno rečeno, alternativnog, dekonstrukcijskog čitanja niza povijesti hrvatskih književnosti kao narativnih, stilski obilježenih i figurama (odnosno tropima) zasićenih književnih tekstova (cf. White 1978). Upravo u trenutku kad se „činjenice” ne samo upisuju, već i čitaju kao tropi, započinje zapostavljanje uočavanja i analiziranja diskurzivnih odnosa između vremena pisanja i vremena čitanja (s uvijek prisutnim odnosom prema ispripovijedanom vremenu), a pri/povijest se, kao fingirani analitički diskurs, pretvara u prepričavanje priče koja teče kao kontinuitet razumijevanja (i ponavljanja) tog pri/ povijesnog, dakle konstruiranoga. Riječ je o čitanju autora i umjetničkih tekstova kao fenomena opstojnih u vremenu i čvrsto zadanih, upisivanih gotovo na razini amblema (podsjetimo se samo frazema o Maruliću kao „ocu hrvatske književnosti” ili A.G.M.-u kao „mostu” između nacionalne osviještenosti i europske upisanosti). Tako se u odnosu između podražavanja kontinuiteta i njegova propitivanja uspostavlja napetost. Ona se može pojaviti kao oblik razotkrivanja, interpretacije i sistematiziranja povijesnih činjenica, čime se bavi rekonstrukcijski pristup, ili kao interpretacija narativnih postupaka pripovjednog aspekta žanra, čitanja stereotipa i ideologemski zasićenih pozicioniranja autora-kazivača, što je predmet dekonstrukcijskog čitanja (pristupa). Konstrukcijski, metodološki pročišćeni primjeri u hrvatskoj su književnoj historiografiji mnogo rjeđi. 
U praksi ovoga konkretnog čitanja naglasak je na povijesno-književnim i teorijskim pitanjima (fenomenima) moderne i Antuna Gustava Matoša, odnosno njihovoj (re)konstrukciji u književnim povijestima. S jedne strane ovi su primjeri uzeti zbog toga što se vrlo detaljno rekonstruiraju u gotovo svim sintetičkim književnim povijestima. S druge strane oni upravo $\mathrm{u}$ tim rekonstrukcijama istovremeno predstavljaju vrlo indikativne primjere čitanja književne povijesti kao pripovijesti. Njih se može čitati kao relativno stabilne i u vremenskom slijedu (kontinuitetu dijakronije) prenosive ideologeme, proizvedene u obliku čvrstih mjesta identifikacije i ideološke nominacije. To je u tradiciji nacionalnog kanona učinjeno kroz postupak upisivanja u dijakroniju povijesno-književnoga sintetičkog žanra. Tako dolazi do udvajanja interpretacijskog zahtjeva koji se nameću čitatelju metateksta: s jedne se strane postavlja pitanje analitičke prakse i imenovanja, odnosno povijesno-empirijske identifikacije, a s druge je riječ o mehanizmima proizvodnje i podražavanja stereotipa, ponajprije kroz proces oblikovanja jezika koji će ih kao relativno stabilne entitete i jake označitelje prenositi kroz različite promjene ideoloških odnosa unutar svake pojedinačne (promjenljive i privremene) kulturne i političke hegemonije. Neovisno o tome je li prevladavajuća kulturna paradigma kolonijalna, unitarna, socijalistička, liberalna ili nacionalistička, stabilnost proizvedenog narativa i njegova stereotipizirana „konstantnost” u promijenjenim ideološkim okolnostima još će izravnije otkrivati one stilski, retorički i ideologemski različite i često prikrivene indikatore kroz koje će biti prepoznavane intencije autora povijesnih prikaza i njihovo ideološko pozicioniranje u odnosu na podražavani okvir foucaultovski shvaćenog režima istine. Ovdje sugeriram kako se upravo na tim mjestima otvaranja zijeva između moći i teksta sintetički karakter i relativna zatvorenost žanra nacionalne književne povijesti otvaraju prema mogućnostima primjene dekonstrukcijskog postupka. To se postiže s jedne strane dekodiranjem ,napuklina u dogovorenom slijedu stereotipiziranog kontinuiteta", a s druge dekodiranjem intencija autorske instance koja taj stereotip koristi kao čvrsto mjesto u svojoj težnji (žudnji) za konsenzusom (struke i sustava moći). Uz ukazivanje na nemogućnost da se u konačnici obavi strukovno (filološki) osviještena, objektivna i pouzdana rekonstrukcija „činjenica”, a da se ipak ostane u zadanom narativnom žanru, dekonstrukcijski postupak ukazuje na ona mjesta u tekstu gdje upisivanje tih filološki ovjerenih činjenica u narativni žanr razotkriva namjere 
pripovjedača/autora (povijesti književnosti), odnosno njihove specifične autorske intencije kako na razini fabule (povijesti), tako i na razini struke, to jest književno-teorijske interferencije s narativnim. Pri tome valja uvijek imati na umu ono na što ukazuje Munslow: povijesni je žanr po svojoj prirodi narativan (2006: 36). Time se otvaraju dvije dobro poznate dvojbe: je li to hendikep ili prednost pisca povijesnog (povijesno-književnog) teksta i njegove rekonstrukcije „stvarnosti”? i gdje je onda u tom žanru mogućnost ovjere onog tekstualnoga koje pretendira na znanstvenost (konstrukciju)?

\section{3.}

Iz tog se razloga u središte dekonstrukcijski motiviranog pristupa povijesnom tekstu postavlja odnos sintetične preglednosti i analitičkog uslojavanja pojedinačnosti što se događa kroz naoko kontradiktorni proces upisivanja ,činjenica" u fabulirani žanr, odnosno u njegov zaplet. Ovdje mislim da ne bi bilo loše izravnije parafrazirati Munslowa i njegovu za engleski jezik prilično nespretnu i stilski vrlo obilježenu dvostruku negaciju: povijest se, naime, ne može ne-ispričati. Isto vrijedi i za književnu povijest u kojoj zbog prirode žanra književni pokreti i autori postaju agensi radnje više ili manje koherentne pri/povijesti s ponovljivim karakterom i slojem prenosivih fabularnih elemenata (gotovih narativnih sekvenci). Znači, funkcija se ovoga narativnog žanra ne mijenja, baš kao ni temeljni odnosi agensa u fabularnom tijeku. Mijenjaju se uglavnom načini na koji se fabularno upisuje u cjelinu te autorska impostacija, često upisivana kroz izravnu prisutnost autorskog glasa koji se ne skriva iza fabularnog sloja zadanog zapleta niti iza udobnosti u prostoru ovjerljive metodologije struke. Umjesto toga, prenoseći gotove formule, autor u ovom žanru ima mogućnost vješto stilski prikrivati vlastitu ideološku impostiranost i retorički obilježeni tip nagovora koji stoji iza prijenosa narativnih sekvenci u okvir ovjere struke (filološke analitičnosti).

\section{4.}

Zanimljivo je iz te perspektive pogledati načine ulančavanja tog (filološki impostiranog i znanstveno-analitički intencijski naturaliziranog) zapleta 
i autorskih intencija koje ga prepoznaju kao zaplet. Ovdje mogu dati samo nekoliko kratkih primjera. Tako se, recimo, Frangešova Povijest hrvatske književnosti (1987) svojom strukturom odupire priči (stereotipu) o kontinuitetu naracije. To čini na formalnoj razini, uspostavljanjem relativno oštrih rezova između odlomaka (ali ne i grafički odvojenim cjelinama). Miroslav Šicel pak u svom nizu hrvatske povijesti književnosti od pet knjiga odvaja autore u posebno grafički odjelite cjeline i pokušava stvoriti privid enciklopedijskih natuknica, odnosno preglednosti uvida. To dovodi do svojevrsne napetosti s prirodom narativnog žanra, što njegovu Povijest hrvatske $k n j i z ̌ e v n o s t i^{1}$ razbija na manje fabulirane cjeline, unatoč tendenciji autora da se, za razliku od svojih prijašnjih knjiga, oslobodi pri/povijesti kao žanrovske dominante. Čini to u pokušaju stvaranja metodološki osviještenog promišljanja povijesti kojem će priča biti tek forma u koju će upisivati filološko-činjenični sloj kao prevladavajući. Problem koji to uvjetuje vezan je uz balansiranje činjenica (ideološki intencijski sloj) u formi neprimjernoj intenciji teksta (priči). Jelčićeva je pak Povijest hrvatske književnosti (1997) svjesna žanra, čak ga i podražava kao okvir ideološki osviještenom iskazivanju autorskog pozicioniranja, čime se na razini fabule postiže jasnost ulančavanja, a na razini retoričke impostacije jasnost i suradnja čitatelja. Jasna određenost autora prema upisanom ideologemskom sloju s jedne strane tekstu daje na protočnosti, a s druge sugerira prihvaćanje konsenzusa oko (ipak) fikcijskog karaktera žanra (a onda i onoga što se u njemu nudi kao niz činjenica). Dekonstrukcija takvog konstrukta, odnosno žanrovske pripadnosti, zapravo se onda upisuje usuprot tipu re-konstrukcije koju je tekst jasno sugerirao te, i bez htijenja analitičara-teoretičara, i sama zadobiva ideološku zasićenost i onaj tip ukazivanja na ideologiju čitanja koji je karakterističan za hegemoniju odnosa u diskursu kojim je zadana (na teorijskoj razini cf. Eagleton 1991 i 2005; Compagnon 2007; Jameson 2009).

Kod Slobodana Prosperova Novaka pitanje je pak ideologijske upisanosti potisnuto u drugi plan, ali je svijest o žanru potpuna i naglašeno autoreferencijalna, tako da je u njegovoj Povijesti hrvatske književnosti (2003) priča o Matošu na primjer uklopljena u dominantni tijek osviještenog i stipuliranog narativa kontinuiteta kao središnje karakteristike pri/povijesnog

1 U ovom tekstu reference i rasprava vezane su isključivo uz ,narativne paragrafe” (cf. Šicel 2005). 
žanra. Nema posebne natuknice o važnom autoru (kao kod Šicela), odvajanja odlomaka i tekstualno relevantnog, odnosno ispričanog (kao kod Ive Frangeša) ili opreznog upisivanja u tijek perspektivom zadanog kontinuiteta uz jasan ideologemski zasićeni glas autorstva (Jelčić). Ali nema niti kontekstualizacije prostora i vremena (odnosa društvene energije i moći) karakteristične za novohistoricističke i suvremene francuske povijesti književnosti, a koja je bila prisutna u njegovu nizu povijesti (starije) književnosti. Tekst (naracija) teče tako da se u priču o Matošu čitatelja uvodi kroz prijelazni narativni paragraf o metafizici nelagode, zatim slijedi misao o duhovnim avanturama kraja stoljeća te potom uklapanje nove priče (o Matošu) u okvir avanture i mučeništva s uokvirivanjem lika (Matoša) koji nosi radnju. Kratka i zaokružena (pri)povijest o Matošu završava pismom koje je ovaj 1913. napisao Tuciću, a otuda se tijek zapleta okreće ,liku” Srđana Tucića. Zanimljivo je napomenuti kako na formalnoj razini iskaza sličan konstrukt, zapravo, prevladava i kod Jelčića, unatoč posve drugačijoj namjeri teksta. Matoš je ovdje potpuno uklopljen u priču o književnim amaterima na početku i prijelaz prema raspravi/priči najprije o Milanu Ogrizoviću, a onda i Ljubi Wiesneru na kraju dijela koji se bavi njime kao agensom fabule. No kod Jelčića ovo nije pravilo kroz cijeli tijek njegove priče, naracije hrvatske književne povijesti, te predstavlja samo formalnu poveznicu dijelova fabule u kojima se pokušava postići ravnoteža između dominacije fabularnog sloja i analitičnosti činjeničnog, to jest metodološki osviještenog uvida onako kako ga on vidi iz intencijski obilježene perspektive. Ta stalnost ukazivanja na diskurzivno zadanu perspektivu koju je zauzeo autor time upisivanju stereotipa daje još veće značenje.

\section{5.}

Uz same načine na koje povijesti (hrvatske) književnosti upisuju fabulu pri/povijesnog kroz jedini ovjereni žanr (onaj narativni), mislim da je važno na razini dekonstrukcijskog čitanja uočiti kako se u diskurzivno zadanim okvirima (odnosa moći, intencija čitanja i pisanja te režima istine) upisuje i (narativno i intencijski) stipulira sloj stereotipiziranja, a onda i dogovorljive (a često i unutar određene hegemonije odnosa dogovorene) prenosivosti tih stereotipa, odnosno na razini fabuliranja upisanih mitologema 
i ideologema (čvrstih mjesta naracije). Taj se proces na razini iskazivanja zbiva kroz odnos fabuliranja i upisivanja sintetičko-činjeničnog sloja, što s jedne strane proizvodi dinamiku ovih tekstova, a s druge strane upravo ih taj prostor susretišta fikcije i faktografski upisanog destabilizira i neprekidno ukazuje na njihov unutarnji režim istine, odnosno mjesta na kojima iza činjenica progovara ideološko impostiranje i namjera tekst(ov)a. To se odnosi na foucaultovski zamišljen prostor zadanosti subjektova okvira, a time i ograničenje fenomenoloških mogućnosti pisanja pri/povijesti kao objektivnog teksta. Svijest o tome nije jednako prisutna u vidljivim intencijama teksta kod različitih autora.

Zato u tako zadanom teorijskom okviru, onom koji tekstom upisano balansira između naracije i sinteze, o nizu autora koji su pisali sintetičke povijesti književnosti, od Vodnika i Kombola, preko Ježića i Barca do Frangeša, Jelčića, spomenutog već Šicela, pa zatim Novaka i drugih, možemo govoriti ne samo kao o povjesničarima književnosti, filolozima koji su ostvarili određene povijesne sinteze hrvatske književnosti nego i kao o pripovjedačima, ali i ideološki osviještenim manipulatorima (po samoj prirodi korištenja medija: privremenosti jezika i odnosa snaga u diskursu moći). Oni su u narativnoj formi ispripovijedali priču o književnom kontinuitetu. To je priča koju je uvijek uokvirivalo nekoliko stereotipa, odnosno elemenata narativnog zadavanog odnosima u sustavu struke (filološke hegemonije) i odnosima u polju kulturalne dominacije. U kontinuitetu književnog i kulturalnog polja te su stereotipizirane slike zadobivale moć i snagu amblematičnog koju je uvijek prisutna „priča o moći kontinuiteta” proizvela, ili je bitno utjecala na oblik odnosa u tekstu (fabule). Riječ je o tipu sučeljavanja simboličnog i alegorijskog značenja, odnosno o ,čvrstim odnosima” koji se također mogu čitati kao posredna ili neodlučna alegorija (cf. Todorov 1977) tako da se iza dogovorenog sloja razvoja (nacionalne paradigme ili književnosti općenito) uvijek može čitati ideološka zasićenost polja, prisutnost koje potkopava jedinstvenu sliku (konsenzus struke, dogovor o kanonu, smjeni formacija pa katkad čak i ideju korpusa). U osnovi tako projiciranog simboličnog kao temelji upisana su čvrsta mjesta, odnosno veliki ideologemi koji se prenose kroz različite režime istine i nastavljaju funkcionirati kao jaki označitelji u različitim državama i sistemima koji čine okvir hrvatskoga kulturnog prostora (kontinuiteta). Oni su zadobili snagu neupitnosti, okamenjenog simboličnog, zajedničkog mjesta identifikacije (i amblema 
i alegorije). Veza odnosa uspostavljene moći pri tome je povratna: s jedne strane ovakve nacionalne pripovijesti proizvode takav kulturalni režim istine kao trajnu kulturalnu vrijednost, a s druge strane ove pripovjedne inteligencije (autorstva povijesnih tekstova) zadane su i same tako nametnutim odnosima unutar diskursa. Među te ideologeme (preživjele i dogovorene, teško razgradive velike priče) spadaju ideologemi tisućljetne kulture i (nacionalnog) kraljevstva, ideja kontinuiteta, državnosti, prava na samoopredjeljenje i konstantnog nijekanja povijesti kao niza kolonijalnih zavisnosti. Tu su i oni oko kojih konsenzus ne mora biti upitan i koji su uokvireni kulturalnim poljem (A.G.M., Marko Marulić). Uz ta čvrsta mjesta pozitivne identifikacije ide i nijekanje mentaliteta koji je bitno obilježen kolonijalnim odnosima (odnosno realnim upisivanjem povijesno dekonstruiranih odnosa u prostoru) što je također jedan od čvrstih stereotipa. Umjesto postupka dekonstrukcije razvila se priča (umreženi niz priča-konstrukcija ${ }^{2}$ ) o pripadnosti zapadnom krugu kao dominirajućem kulturalnom čimbeniku i samostalnosti (kulture i politike) unutar okvira većih političkih i strateških cjelina ${ }^{3}$.

Ti su okviri stipulirani kroz povijesno narativno i prirodu žanra koji se na razini prijenosa sadržajnog sloja (označenog) na taj način čita tijekom proteklih 150 godina (od vremena zakašnjelog romantizma - konsolidacije nacionalne ,priče”). Taj postupak okamenjivanja privremene prakse iskazivanja zbiva se dakle ulančavanjem označiteljske prakse. Unutar tako zadanog okvira tako strukturirano narativno uglavnom se prepoznaje kao „činjenično”, a stereotipizirana mjesta kao povijesne istine. One su često u funkciji neupitnih i ideološki jakih simboličnih iskaznih podražaja koji održavaju stabilnosti priče, odnosno narativne vjerodostojnosti, u odnosu na označeno u (proizvedenoj) povijesnoj istini. Otuda važnost pridavanja

${ }^{2}$ U Munslowovoj klasifikaciji (2006) konstrukcijski postupak najbliži je mitskom mišljenju, zamjeni priče i povijesti. Re-konstrukcija, premda izvedena iz racionalističke pozicije „subjekta kao središta svijeta” ipak korespondira s dekonstrukcijskim zahtjevom o razmatranju odnosa moći u prostoru upisivanja povijesnog teksta (narativa). Konstruktivističke teorije, premda vezane uz određeni projekt (strukturalistički, marksistički, fenomenološki) ipak u svojoj osnovi priču/koncept nadređuju odnosima u pojedinačnim povijesnim realizacijama ispripovijedanog.

${ }^{3} \mathrm{O}$ tome je, doduše intuitivno i bez uokviravajuće diskurzivne pozicije, pisao Krleža u nekoliko svojih eseja od kojih mi se u ovom kontekstu najzanimljivijim čini esej Nekoliko riječi o malograđanskom historicizmu uopće, prvi put objavljen u „Književnoj republici” 1926. godine. 
pozornosti jezičnim igrama stipuliranim na razini političke i retoričke iskazne prakse, odnosno stilističke obilježenosti. Tome je tako i na području povijesti književnosti.

U dekonstrukciju takvog modela povijesnoga ,činjeničnog” okvira ne može se poći od općih mjesta (i proizvesti jednako jaki efekt ideološke zasićenosti stilom, politikom tekstualnoga i ideološki zasićenoga), već od onih narativnih čvrstih paragrafa, odnosno ideologemskih cjelina čija se aproprijacija otvara različitim tumačenjima na razini narativnog postupka i stilskoretoričkih sredstava kojima je narativni kontinuitet podražavan/poništavan kroz različite sinteze. Naime, koliko se god (pri)povijest ispisuje na razini interpretacije izraza, toliko se također prepričava priča na razini prethodnih praksi ispisivanja i njihova polifona odjeka u novom ideološkom i diskurzivnom okviru.

Čini mi se kako se tom specifičnom formalnom problemu povijesti (književnosti) kao naracije (fikcije) u našem nacionalnom kontekstu najbolje može pristupiti analizom suvremenih i diskurzivno zasićenih konstrukcija i rekonstrukcija paradigmatskih autora/likova/ideologema 20. stoljeća. Tu je riječ o amblematičnosti nižeg stupnja od one upisane u „velike priče”, ali koja svojom slojevitom upotrebom stilski ipak sugerira upravo taj aspekt ispisivanja kontinuiteta (npr. često citirani/naturalizirani stihovi: „Dok je srca bit će i Kroacije").

U tom smislu imena Antuna Gustava Matoša, Vladimira Nazora, Miroslava Krleže, Ive Andrića i njihovih književnih opusa, odnosno re/konstrukcije njihovih autorskih intencija predstavljaju izuzetno prijemčiva mjesta mogućega najizravnijeg suočavanja s povijesnim diskursom kao tekstom zasićenim ponavljanjem i ideološkim uslojavanjem autorske intencije (tvoraca književnih povijesti i njihovih diskurzivnih okvira). Ideologija se u ovim tekstovima proizvodi na dvjema razinama, onoj osviještenoj, koja podražava određeni hegemonijski okvir, i onoj prikrivenoj, koja se pojavljuje na razini ironijske dekonstrukcije (ili samo destrukcije?) figurativnog svijeta ispričanoga. Kao što je spomenuto na početku, način na koji se nesvjesno proizvodi ideološki zasićeno u ovakvim naoko objektivnim tekstovima koji prenose zadani tematski okvir (dakle, način na koji se podriva stabilnost priče) uočljiviji je u konstrukciji likova i radnji oko kojih postoji privid konsenzusa (Matoš kao „velika sinteza lokalnog i kozmopolitskog”, Krleža kao „najveći pisac dvadesetog stoljeća”, Marulić, još jednom, kao 
„otac hrvatske književnosti”, Nazor kao „primjer sinteze hrvatstva i jugoslavenstva” s „upisanom nacionalnom sviješću” itd.). Tako kad se na primjer u ovom kontekstu čita Andrić, onda se - načinom na koji se kod nekih autora prešućuje, kod drugih upisuje kao ,rani Andrić koji pripada hrvatskoj književnosti”, a kod trećih navodi ,(i) kao hrvatski književnik” - dosta izravno može pročitati upravo ideološko pozicioniranje autorske intencije književnog povjesničara/pripovjedača. Kad se pak čita konstrukt imenovan „Matoš”, različite povijesti književnosti na prvi pogled izgledaju kao da upisuju kontinuitet jedinstvene, konsenzusom dogovorene priče. Raslojavanje započinje tek iščitavanjem dubinskih intencija teksta (odnosno tekstova), odnosno njegove (njihovih) putanje razumijevanja (Stojanovićeva definicija pozicioniranja ironijske destabilizacije trase čitanja $)^{4}$.

Zanimljiva je pri tome sama činjenica da se Matoša stereotipizira ne samo na razini simbola određenog odnosa unutar sustava (jedinstvo općeg i nacionalnog, specifični artistički nacionalizam, modernost pristupa i konzervativnost forme u pjesništvu ili ambivalentan i složen odnos prema pitanju hrvatstva i srpstva; Novak na primjer u svojoj Povijesti tome posvećuje gotovo desetinu ukupnog prostora posvećenog Matošu), već i simboliziranjem izvan samoga književog polja, na najšire zamišljenom području nacionalne kulture kao (pri)povijesti koja teče. Tako se grafemski njegovo ideologemski i kulturološki zasićeno stereotipizirano mjesto u povijesti kulture i teorijski definiranom kulturalnom polju može sažeti na tri slova koja predstavljaju prepoznatljivi amblem (i istovremeno njegovu alegorijsku destabilizaciju): AGM. U tom i takvom reduciranju može se čitati posve jasna uloga podražavanja ove (odnosno ovakve) priče u proizvodnji nacionalnog konsenzusa i pripovijesti o kontinuitetu. Ta kulturalno jaka mjesta i u drugim rubnim kulturama često proizvode alegorije čitanja: ona su s jedne strane dogovorena (kulturnim konsenzusom), a s druge su središnja mjesta destabilizacije jedinstvenog ,nacionalnog” pogleda na zajedničku (pri)povijest. No taj odnos između jakog označitelja i privremenosti označavajuće

${ }^{4}$ Činjenica da se u čitanju ovih koncepata može sugerirati čitanje na razini alegoreze, iza površinskog sloja otvara mogućnost da se povijesno-književnim sintetičkim pri/povijestima prilazi kao alegorijskim tekstovima. To bi se možda moglo tumačiti u skladu Jamesonovih postavki o ideološkim aspektima teorijskog čitanja. Sama priroda narativnih žanrova zahtijeva ne samo čitanje koje nosi ironijsku destabilizaciju, nego i slojevitost „dubinskih slojeva” (alegorezu i alegorijske slojeve proklizavanja). 
prakse (jezika) upitan je u procesu uokvirivanja svake strukture, ne samo onih rubnih, kako to sugerira Bhabha. Uostalom, na to je upozorio još Derrida, na kojega se Bhabha (1994) poziva.

Ono mjesto, dakle, gdje se otvara problem čitanja svakoga upisanog amblema jest prostor ironičnog potkopavanja stabilnog značenja koji se nalazi u prirodi shvaćanja jezika kao privremenog poretka (odnosa moći). Okamenjena struktura je ostala, ali njezino značenje je podrovano utvrđivanjem privremenosti svakog poretka (episteme), ali i sviješću o nemogućnosti povijesne rekonstrukcije, odnosno zapitanosti nad hipotezom da je svaka rekonstrukcija ideološki proizvod. Dekonstrukcijski postupak koji označiteljske prakse upućuje jednu na drugu (ostavljajući sāmo označeno na vjetrometini ne-značenja) ukazat će u tom smislu na svu arbitrarnost čitanja stereotipa „AGM” u takvim okamenjenim i dogovorenim uvjetima te potrebu za njegovim upisivanjem u čitanje iz određenih ideološki osviještenih i manipulacijama sklonih pozicija koje su realizacija različitih oblika (ponovljive) privremenosti. Upravo svijest o toj povezanosti označiteljskih praksi važna je za osvješćivanje filološkoga u povijesnom diskursu kojim dominira naracija.

6.

Utoliko Compagnon nije potpuno u pravu kad kaže da u žanru povijesti književnosti prevladava povijesno koje više-manje uspješno potiskuje metodologiju autohtone epistemologije. Pokušaji upisivanja analitičkih slojeva u narativno, uz korištenje relevantne književno-znanstvene metodologije, prisutni su u hrvatskoj književnoj historiografiji još od Vodnika i Kombola, a određenu ravnotežu dobivaju kod Barca, premda su u smislu uvažavanja i stipulacije naracije kao dominantne osobine žanra kod njega još uvijek, čini mi se, neosviješteni.

Tek je postmoderni pristup osvijestio činjenicu da se pisanje upravo tako uslojena teksta često oblikuje usuprot intencijama autora. Naime, figurativni oblici koji se nadaju na razini stila kojim je priča ispisana proizvedeni su koliko iz pozicioniranja autorske perspektive, toliko i iz same prirode žanra. Tako su proizvedene narativne strukture i mehanizmi oblikovanja figurativnog govora (velikih tropa; cf. White 1978) utjecali ne samo na 
fikcionalizaciju povijesnog diskursa, već i na nagoviještenu već proizvodnju stabilnih stereotipa (mitologema) i čvrstih fabuliranih mjesta (odnosno temata) ideologemske identifikacije naracije nacije.

Čitanjem različitih povijesti književnosti može se zaključiti kako upravo zahvaljujući stabilnosti postupka prijenosa priče, kanon ostaje čvrst i relativno nepropustan prema naknadnim nasrtajima i upisivanjima drugačijega ideološkog pozicioniranja diskursa moći u stabilno i relativno statično polje. U samom uspostavljenom polju vlada privid prešutnog konsenzusa oko tipa naracije i prirode figurativnosti književne (pri)povijesti nacije. Upravo na tom mjestu može se iščitati i paradoks ovako zamišljenoga de/kodiranog ideologemskog sloja koji stipulira ideju stabilnosti polja: u prostoru stabilne slike „stanja stvari” na marginama pripovjedne intencije autorstva pojavljuju se one razlike koje zapravo ideološki bitno razdvajaju pojedine autore i njihove tekstove/pristupe kanonu i ispripovijedanomu uopće.

Te razlike često nisu uočljive niti izražene u opisivanju značaja razdoblja ili autora. Svi se ovdje spomenuti autori slažu i prenose stereotip o moderni kao hvatanju priključka sa Zapadom i o Matošu kao središnjoj ličnosti koja je osobno bila taj priključak. Isto tako kod svih se ističe kompleksni Matošev nacionalni naboj, istovremeno i patetičan i „svjetski”, kao i posebnost njegova mjesta i njegova uloga ,prvog profesionalnog književnika” i kritičara. Čak bi se moglo reći da se različita pozicioniranja susreću i u određivanju moderne kao čvrstog mjesta europeizacije (premda jedini Novak nastavlja Vodnikovu misao o ,europskom značaju” kao konkurenciji i nameće kriterij međunarodne tržišne relevantnosti). Drugačija je stvar kako se iza razine fabularnog sloja upisivanja povijesti, u čitanju vlastite priče iz pozicije autorske intencije razlikuje taj pristup ideologemu Matoševa hrvatstva na primjer. U tom smislu mjesta na kojima se pružaju (razotkrivaju) indikatori za moguće dekodiranje intencija autora pri/povijesnih tekstova i društvene energije koja „kola” njihovim tekstom neizravno ukazuju na perspektivu iz koje je određeni period/autor (re)konstruiran i otvaraju potencijal dekonstrukcije činjeničnoga kako bi se otvorila mogućnost razotkrivanja (i objašnjavanja) određenih mehanizama kojima se vrši reprezentacija povijesne perspektive.

Ovo, dakle, traži detaljno elaboriranje povijesti problema te naratološku i hermeneutičku analizu koje bi mogle pokazati način na koji autorske intencije sudjeluju u oblikovanju stereotipa, kako kroz praksu školske nastave 
književnosti, tako i na razini iščitavanja književno-povijesnog teksta kojih su posljedica određene političke, novinske i druge u zajednici elaborirane ideologemski zasićene impostacije i oblikovana čvrsta mjesta. No ovdje ću samo najaviti moguće primjere čitanja suvremenih i nešto manje suvremenih povijesti književnosti iz kojih se može iščitati način na koji u povijesno književnim sintezama narativno ostvaruje primat nad filološkim (i teorijskim, u smislu propitivanja rortijevski shvaćenog koncepta zdravog razuma i vječitog postavljanja pitanja).

Na tim se mjestima kroz određene indikatore i pomno čitanje napuklina u sustavu vidi (iščitava) izbijanje autorskih intencija u prvi plan. Riječ je i o intencijama zasićenima ideološkim pozicioniranjem, ali prije svega na razini inzistiranja na određenom tipu pristupa koji će zadovoljiti okvire autorske namjere i podčiniti svojoj namjeri stereotipizacijske prakse jedinstvenog upisivanja književnog polja u svrhu podražavanja priče o kontinuitetu i pragmatičnim mogućnostima njegova prevrednovanja. To, dakle, priziva (ponovno) pomno čitanje autora koji su se bavili modernom i Matošem, od Marakovića i Bognera, preko Ježića i Barca, pa sve do suvremenih pisaca čije smo neke pripovjedne taktike prikazali u ovom tekstu.

\section{Literatura}

Ankersmit F.R., 2005, Sublime Historical Experience, Stanford.

Bhabha Homi K., 1994, The Location of Culture, London.

Compagnon A., 2007, Demon Teorije, prev. M. Čale, Zagreb.

Derrida J., 2007, Pisanje i razlika, prev. V. Mikšić, Sarajevo-Zagreb.

Eagleton T., 1991, Ideology. An Introduction, London.

Eagleton T., 2005, Teorija i nakon nje, prev. D. Polšek, Zagreb.

Foucault M., 2002, Riječi i stvari. Arheologija humanističkih znanosti, prev. S. Rehelić, Zagreb.

Frangeš I., 1987, Povijest hrvatske književnosti, Zagreb-Ljubljana.

Jameson F., 2009, Ideologies of Theory, London.

Jelčić D., 1997, Povijest hrvatske književnosti. Tisućljeće od Baščanske ploče do postmoderne, Zagreb.

Krleža M., 1979, Nekoliko riječi o malograđanskom historicizmu uopće, u: Eseji i članci. Sabrana djela Miroslava Krleže, ur. A. Malinar, Zagreb-Sarajevo.

Munslow A., 2006, Deconstructing History, London-New York. 
Novak S.P., 2003, Povijest hrvatske književnosti, Zagreb.

Rorty R., 1989, Contingency, Irony and Solidarity, New York.

Šicel M., 2005, Moderna, sv. 3, Povijest hrvatske književnosti, Zagreb.

Todorov T., 1977, The Poetics of Prose, prev. R. Howard, Ithaca.

White H., 1978, Tropics of Discourse. Essays in Cultural Criticism, Baltimore. 
